\title{
Tüketici Davranışlarının Çevre Dostu Davranış Türleri Kapsamında İncelenmesi: Alanya Örneği
}

\section{Üzeyir KEMENT ${ }^{1}$}

\section{$\ddot{\mathrm{Oz}}$}

$\mathrm{Bu}$ araştırmanın amacı iyi vatandaşlık davranışı, çevreci aktivizm davranışı ve yeşil satın alma davranışına algılanan tüketici etkililiği, çevresel kaygı ve özgecil değerin etkisini incelemektir. Araştırmanın evrenini çevreye duyarlı tesisleri (yeşil oteller) ziyaret eden otel müşterileri oluşturmaktadır. Araştırmanın amacı doğrultusunda 391 yeşil otel müșterisine kolayda örneklem yöntemi ile anket formu doldurtulmuştur. Araştırmada kullanılan anket formları Haziran 2017-Mayıs 2018 zaman aralığında Alanya'da faaliyet göstermekte olan yeşil otellerde konaklayan otel müşterilerine doldurtulmuştur. Araștırma kapsamında oluşturulan model önerisine yönelik geçerlilik, güvenilirlik ve tesadüfilik testleri uygulanmış ve hipotezlerin test edilmesi sürecinde Amos istatistik programında yapısal eşitlik modellemesi gerçekleştirilmiştir. Araştırma sonuçları incelendiğinde iyi vatandaşlık davranışını; algılanan tüketici etkililiği, çevresel kayg1 ve özgecil değerin olumlu yönde etkilediği sonucuna ulaşılmıştır. Ayrıca çevreci aktivizm davranışını; özgecil değer, yeşil satın alma davranışını ise özgecil değer ve çevresel kaygı değişkenlerinin olumlu yönde etkilediği tespit edilmiştir.

\section{Anahtar Kelimeler: Çevre Dostu Davranış, Özgecil Değer, Çevresel Kayg1, Algılanan Tüketici Etkililiği, Turizm}

\section{Investigation of Consumer Behaviors within the Scope of Environmentally Friendly Behavior Types: The Case of Alanya}

\begin{abstract}
The aim of this study is to examine the effects of perceived customer effectiveness, environmental concern and altruistic value on good citizenship behavior, environmental activism behavior and green purchase behavior. The population of the research consists of hotel customers visiting environmentally friendly hotels (green hotels). In line with the purpose of the study, 391 green hotel customers filled in the questionnaire form with convenience sampling method. The questionnaires used in the research were filled in by the hotel guests staying in green hotels in the period of June 2017-May 2018. Validity, reliability and random tests to the research model Structural equation modeling was performed in Amos statistic program for testing hypotheses. When the results of the research were examined, it was concluded that perceived customer effectiveness, environmental concern and altruistic value positively affect good citizenship behavior. Moreover, altruistic value positively affects the environmental activism behavior. Altruistic value and environmental concern positively affect green purchase behavior.
\end{abstract}

Key Words: Environmentally Friendly Behavior, Altruistic Value, Environmental Concern, Perceived Customer Effectiveness, Tourism

\section{Atıf İçin / Please Cite As:}

Kement, Ü. (2020). Tüketici davranışlarının çevre dostu davranış türleri kapsamında incelenmesi: Alanya örneği. Manas Sosyal Arașturmalar Dergisi, 9(1), 209-221.

\footnotetext{
${ }^{1}$ Dr. Öğr. Üyesi - Bingöl Üniversitesi, Beden Eğitimi ve Spor Yüksekokulu, Rekreasyon Bölümü, uzeyirkement@hotmail.com ORCID: 0000-0002-3190-9079
} 


\section{Giriş}

Çevre çalışmalarına yönelik son yıllarda giderek artan ilgi sadece araştırmacılar tarafindan olmamış aynı zamanda işletmeler tarafindan da önemsenmeye başlamıştır (Ahn, Koo ve Chang, 2012). Alanyazında birçok çalışma farklı sektörleri göz önüne alarak çevre dostu davranışları incelemektedir (Han ve Kim, 2010; Kement ve Güçer, 2015; Özer, Kement ve Gültekin, 2015; Kil, Holland ve Stein, 2015; Lee vd., 2014). Örneğin Han ve Kim (2010) yeşil otelleri ziyaret eden bireylerin tekrar ziyaret niyetlerini incelerken, Kement ve Güçer (2015) kamping faaliyetine katılan bireylerin çevre dostu davranışlarını incelemişlerdir. Pickett-Baker ve Ozaki (2008) perakendecilik faaliyeti gösteren işletmelerde kullanılan ürünlerin çevre dostu olmalarılya ilgili bir araştırma gerçekleştirirken, Kilbourne ve Pickett (2008) Amerika'da yaşayan bireylerin çevre dostu davranışlarını incelemişlerdir. Lee vd., (2014) çalışmalarında çevre dostu davranışları incelerken, çevre dostu davranışları açıklayan üç farklı davranış türünden yola çıkarak araştırmalarını gerçekleş̧irmişlerdir. Araştırma Güney Kore'de yaşayan bireylere yönelik gerçekleştirilmiştir. Bu araştırmada Lee vd. (2014) yapılan araştırma model olarak ele alınmış ve Türkiye'de yeşil yıldız uygulamasına sahip otel işletmelerini ziyaret eden otel müşterileri araştırılmıştır. Alanyazın incelendiğinde daha önce, çevre dostu davranışları açıklayan davranış türleri kapsamında Türkiye'de bir araştırma gerçekleştirilmemiştir. Ayrıca yeşil otellerde konaklayan otel müşterileri üzerine çevre dostu davranış türleri bağlamında bir araştırma gerçekleştirilmemiştir. Bu durum çalışmanın özgünlüğünü ortaya koymaktadır.

Farklı çevre dostu davranışlarının açıklanması ve birbiri ile olan ilişkisinin ortaya konması işletmelerin pazarlama uygulamalarına yardımcı olabilir (Ham ve Choi, 2012). Bu bağlamda pazarda uzun vadeli ilişskilerin gerçekleştirilmesine yönelik plan ve politikaların geliştirilmesi bakımından önem arz ettiği söylenebilir. Bu araştırma ile farklı çevre dostu davranış türlerinin konaklama işletmeleri üzerindeki etkisini ortaya koymak ve alanyazında yer almayan bu açığı kapatmak hedeflenmiştir.

Araştırma modeli oluşturulurken öncelikle çevre dostu davranışların oluşumunda önemli olan etmenler üzerine araştırmalar gerçekleştirilmiştir. Yapılan araştırmalar neticesinde bireylerin çevre dostu davranışlar sergilemesinde çevreye yönelik atfettikleri değerin önemli bir unsur olduğu (Lee vd., 2014; Steth, Newman ve Gross, 1991; Zhang, Zhang ve Zhang, 2014) tespit edilmiştir. Ayrica bireylerin çevreci uygulamalar hakkındaki algıları (Bandura, 1994; Berger ve Corbin, 1992; Kement, 2015) ve çevreyle ilgili kaygilarının (Anderson ve Cunningham, 1972; Fransson ve Garling, 1999; Kilbourne ve Pickett, 2008) çevre dostu davranış sergilemelerinde önemli unsurlar olduğu yapılan araştırmalar neticesinde tespit edilmiştir.

Tüm bu incelemeler neticesinde araştırma Lee vd. (2014) tarafindan oluşturulmuş olan araştırma modelini temel alarak turizm sektöründe faaliyet göstermekte olan yeşil otel müşterileri üzerinde uygulanmıştır. Araştırma modeline yönelik geçerlilik ve güvenilirlik çalışmaları yapılmış ve araştırma kapsamında oluşturulan hipotezler Amos programı aracıllğı ile yol analizi ile incelenmiştir. Araştırmada öncelikle kuramsal çerçeve araştırılmış ve hipotezler açıklanmıştır. Literatür çalışmalarından sonra araştırma model önerisine yönelik istatistiki bulgulara yer verilmiştir.

\section{Kuramsal Çerçeve}

\section{Çevre Dostu Davranış}

Toplumsal yönden insanların yaşam kalitelerini artırmak, doğal tahribatların önüne geçilmesi gibi noktalarda çevreye yönelik davranışlar önem arz etmektedir (Stern, 2000; Seguin, Pellerier ve Hunsley, 1998; McFarlane ve Boxall, 2003; Carrington, Neville ve Whitwell, 2010). Bu bakımdan Stern (1999) çevre üzerinde olumlu etki oluşturabilecek davranışlanı; yeşil satın alma davranışı, iyi vatandaşlık davranışı ve çevresel aktivizm olmak üzere üç gruba ayırmaktadır. Yeşil satın alma davranışı, belirli bir mal veya hizmetin satın alınmasına ilişskin çevresel sonuçlarla ilgili endişeleri ifade etmektedir (Moisander, 2007; Scheffer, 1991). İyi vatandaşlık davranışı, yeşil bir ürünün satın alınmasıyla sınırlı olan yeşil satın alma davranışının aksine, çevre ile ilgili olumlu bir etkiye sahip olmak için satın almayla ilişkili olmayan bir etkinlik olarak görülmektedir (Lee, Kim, Kim ve Choi, 2014: 2098). Çevresel aktivizm (eylemci davranış), genellikle çevresel endişeleri gidermek ve bir çevre organizasyonunu desteklemek için hükümet temsilcisi ile iletişim kurmak gibi kamusal eylemleri içeren kolektif bir davranış biçimidir (Edwards ve Oskamp, 1992; Manzo ve Weinstein, 1987). 


\section{Algılanan Tüketici Etkililiği}

Alan yazında bazı araştırmacılar (Fishbein ve Ajzen, 1975; Laroche, Bergeron ve Barbaro-Forleo, 2001) olumlu tavrın belirli bir davranışa yönelmenin göstergesi olduğuna inanırken, bazı araştırmacılar ise (Gupta ve Ogden, 2009; Pickett-Baker ve Ozaki, 2008; Smith, Haugtvedt ve Petty, 1994) tutum ve davranış arasındaki boşluğu (çevre dostu davranış her zaman çevre problemlerini azaltmaya yönelik bir davranış sergilenmesine yol açmaz) uyarmaktadırlar. Tutum ve davranış arasındaki boşluğu uyaranlar genellikle sosyal ikilem teorisini (Gupta vd., 2009; Pickett vd., 2008; Smith vd., 1994) kullanarak açıklamaya çalışmışlardır. Sosyal ikilem, bir grup üyesinin grubun yararlarını en üst düzeye çıkarmak (kişisel kazanımlarını feda etmek) ve menfaat edinmek isteği ile ayrımcllıkla karşı karşıya kalması durumudur (Lee vd., 2014: 2099). Örneğin, su tasarrufu için yazı kampanyası başlatan bir topluluk yaz sezonu boyunca çimlerin sulanmamasını talep etmektedir. Bir birey için en doğrusu çimlerin sulanmasını istemesi olacaktır. Fakat herkes sulamayı seçerse içme suyu bittiği zaman herkes bundan sorumlu olacaktır. Öte yandan bir birey çim sulamayı seçmezse kişisel çıkarlarını feda etmektedir. Böylece biri sosyal ikilemdedir çünkü hiçbir seçenek onun için ideal sonuç doğurmaz. Böyle bir sosyal ikilem durumunda, algilanan tüketici etkinliği kişinin kararını ve davranışını açılamaya yardımcı olmaktadır (Bandura, 1994; Ellen, Wiener ve CobbWalgren, 1991). Güncel pek çok çalışma (Lee vd., 2014; Zhao, Gao, Wu ve Wang ve Zhu, 2014; Cho, Thyroff, Rapert ve Lee, 2013; Vicent-Monila, Fernandez- Sainz ve Izagirre-Olaizola, 2013) algilanan tüketici etkinliğinin, çevreci davranışlar üzerinde etkisini ispatlamıştır. Ayrıca Lee vd. (2014) hazırladıkları çalışmada algıllanan tüketici etkililiğinin çevre dostu davranış üzerinde etkisi olduğunu tespit etmişlerdir. Bu doğrultuda araştırmada algilanan tüketici etkililiğinin çevre dostu davranış üzerindeki etkisini incelemek amaciyla şu hipotezler kurulmuştur.

$\mathrm{H}_{1}$ : Algılanan tüketici etkililiği yeşil satın alma davranışını olumlu yönde etkiler.

$\mathrm{H}_{2}$ : Algılanan tüketici etkililiği çevresel aktivizm davranışı olumlu yönde etkiler.

$\mathrm{H}_{3}$ : Algıılanan tüketici etkililiği iyi vatandaşlı davranışını olumlu yönde etkiler.

\section{Çevresel Kayg1}

Çevresel kayg1, tüketicilerin çevreye yönelik tehditlerden ne kadar endişe duyduğunu gösteren tutumları şeklinde tanımlanmaktadır (Chan, 2001; Ishawini ve Saroj, 2011; Pinto, Nique, Anna ve Herter, 2011). Diğer bir ifadeyle, bireylerin çevresel sorunlara yönelik farkındalık düzeyi ve çözüm geliştirme konusunda isteklilikleri olarak ifade edilmektedir (Akehurst, 2012: 977). Çevresel etkilerin incelendiği çeşitli çalışmalarda (Chan, 2001; Kement, 2018; Kement ve Güçer, 2018; Minton ve Rose, 1997; Pinto vd., 2011) kaygının, çevre dostu davranış üzerinde etkisi olduğu gözlemlenmektedir. Doğayı koruyan bireyler, yaşamlarında da bu doğrultuda eylemlerde bulunmaktadırlar. Dolayısıyla, çevre dostu ürünleri satın alırlar, kaynağ1 az olan ürünlerin tüketimini azaltırlar (Roberts ve Bacon, 1997: 86). Ellen, Wiener ve Cobb (1991) yaptıkları araştırmada çevresel kaygının çeşitli çevre dostu davranış türleri üzerinde önemli etkiye sahip olduğunu tespit etmektedirler. Benzer şekilde, çevresel kaygının çevre dostu davranış üzerinde etkisini inceleyen Ishaswini ve Saroj (2011), ikisi arasında olumlu bir ilişki olduğunu tespit etmişlerdir. Bu önceki çalışmalar, çevre hakkında endişe edenler için yeşil satın alma davranışı, iyi vatandaşlık davranışı ve aktivistik davranışın önleyici davranışlarda bulunma olasılıklarının daha yüksek olduğunu ortaya koyuyor. $\mathrm{Bu}$ nedenle, aşağıdaki hipotezlerin test edilmesi amaçlanmıştır;

$\mathrm{H}_{4}$ : Çevresel kayg1, iyi vatandaşlık davranışı üzerinde olumlu bir etkiye sahiptir.

$\mathrm{H}_{5}$ : Çevresel kayg1, çevresel aktivizm davranışı üzerinde olumlu bir etkiye sahiptir.

$\mathrm{H}_{6}$ : Çevresel kaygı, yeşil satın alma davranışı üzerinde olumlu bir etkiye sahiptir.

\section{Özgecil Değer}

Schwartz (1992: 21) değeri; bir kişiden veya toplumsal gruptan beklenen ve önemi durumdan duruma değişen rehber niteliğindeki hedefler olarak tanımlamaktadır. Başka bir deyişle değer; bir bireyin inanç ve tutumlarını organize etmenin ve bireyin davranışlarına yön vermenin temelini oluşturan yönlendirici ilkelerdir (Stern ve Dietz, 1994; Stern, Dietz ve Guagnano, 1995). Stern (2000)'e göre değer; biyosferik, özgecil ve egoistik olmak üzere üçe ayrılmaktadır. Ayrıca bu kategoriler ekolojik dünya görüşüyle ilişkilidir.

Biyosferik değer, doğa ve biyolojik ortamı ifade etmektedir. Diğer yandan özgecil değer, başkalarının refahını gözeten bir değer boyutunu ortaya koymaktadır. Son olarak egoistik değer ise bireylerin 
kazançlarını maksimize etmeyi vurgulamaktadır (De Groot, Steck ve Dicke, 2007; Klöckner, 2013). Biyosferik değeri yüksek olan kişiler, düşük biyosferik değeri olan kişilere göre çevreye kirliliğine, küresel 1sınmaya ve doğal alanlarda oluşan tahribatlara karşı daha çok endişe etmektedirler (De Groot vd., 2007; Stern, 2000). Birçok araştırmacı özgecil değer ile çevresel aktivist davranışı (McCarty ve Shrum, 1994), iyi vatandaşlık davranışı ve yeşil satın alma davranışı arasında olumlu yönde ilişki olduğunu bulgulamıştır (Cameron, Brown ve Chapman, 1998; Lee vd., 2014; Li, 1997). Alanyazında yapılan bazı çalışmalarda (Joireman, Lasane, Bennet, Richards ve Solaimani, 2001; Joireman, Van Lange, Kuhlman, Van Vugt ve Shelley, 1997; Van Vugt, Meertens ve Van Lange, 1995) özgecil veya biyosferik değeri ön planda tutan bireylerin çevreye karşı daha bilinçli davranış sergiledikleri, egoistik değeri ön planda tutan bireylerin ise çevreye karşı bilinçli davranış göstermedikleri sonucuna ulaşılmıştır. Ayrıca özgecil değerin hem sosyal hem de biyosferik boyutlarının çevreye yararlı bir şekilde davranma yatkınlığı ile ilişkili olduğu bulunmaktadır (Jansson, Marell ve Nordlund, 2010). Özgecil değerin üç çevre dostu davranış türü üzerindeki etkisini incelemek amaciyla şu hipotezler kurulmuştur.

$\mathrm{H}_{7}$ : Özgecil değer, yeşil satın alma davranışı üzerinde olumlu bir etkiye sahiptir.

$\mathrm{H}_{8}$ : Özgecil değer, çevresel aktivizm davranışı üzerinde olumlu bir etkiye sahiptir.

$\mathrm{H}_{9}$ : Özgecil değer, iyi vatandaşlık davranışı üzerinde olumlu bir etkiye sahiptir.

\section{Yöntem}

Bu araştırma çevre dostu davranışlara algilanan tüketici etkililiği, çevresel kayg1 ve özgecil değerin etkisini tespit etmek amacıyla yapılmıştır. Çalışmanın amacı doğrultusunda oluşturulan araştırma model önerisi Şekil 1'de detaylı olarak gösterilmektedir.

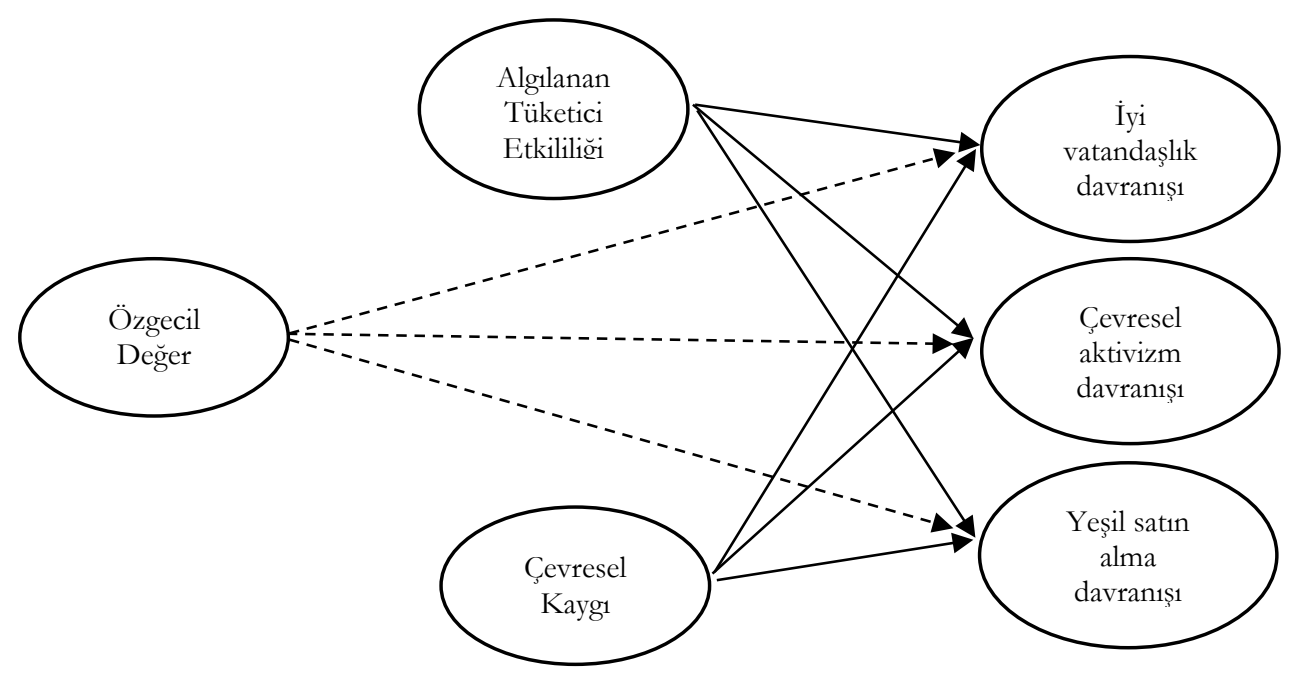

Şekil 1. Araștirma Model Önerisi

\section{Evren - Örneklem}

Alanya'da yer alan yeşil otelleri ziyaret eden otel müşterileri araştırmanın evrenini oluşturmaktadır. Alanya'da yeşil yıldız belgesini bünyesinde barındıran 47 adet konaklama işletmesi (Kültür ve Turizm Bakanlığ1, 2018) bulunmaktadır. Ancak bu konaklama işletmelerini ziyaret eden müşteri sayısına ilişkin istatistiki bir veriye rastlanılmamaktadır. Alanya'da faaliyet gösteren yeşil otelleri bir yil içerisinde ziyaret eden otel müşterilerinin sayısının 10.000 'den fazla olduğu varsayllarak örneklemin hesaplanmasına karar verilmiştir. Örneklem büyüklüğünün hesaplanması için Krejcie ve Morgan (1970) tarafindan önerilen tablodan yararlanılmıştır. Örneklem büyüklügü için 0,05 anlamllık düzeyinde ve 0,05 örneklem hatasında belirtilen 10.000 'den büyük evren büyüklüklerinde 387 sayısı örneklem için yeterli bulunmaktadır (Ural ve Kilıç 2006). Araştırma kapsamında 405 anket formu 2017 Haziran-Ekim ayları arasında Alanya'da bulunan yeşil otellerde konaklayan otel müşterilerine uygulanmıştır. Anket formunun uygulanacağ otel müşterilerinin seçiminde kolayda örneklem metodundan yararlanılmıştır. Otel müşterilerine uygulanan 405 anket formundan 14 tanesinde eksiklerin olması sebebiyle 391 anket formu değerlendirmeye tabi tutulmuştur. 


\section{Veri Toplama Araçları}

Araştırma kapsamında kullanılan anket formu iki bölümden oluşmaktadır. Birinci bölümde katılımcıların demografik özelliklerini belirlemeye ilişkin sorular yer almaktadır. İkinci bölümde araştırma kapsamında oluşturulan model önerisinde yer alan ölçeklere ilişkin sorular bulunmaktadır. Algılanan tüketici etkililiğini ölçmek için 4 soru (Kim ve Choi, 2005), çevresel kaygıyı ölçmek için 4 soru (Dunlap, Van Liere, Mertig ve Jones, 2000), özgecil değeri ölçmek için 8 soru (De Goot, Steg ve Dicke, 2007) ve çevre dostu davranış1 ölçmek için 13 soru (Karp, 1996; Mostafa, 2007) kullanılmıştır. Çevresel kayg1 soruları Yeni Ekolojik Paradigma (YEP) teorisinden uyarlanmıştır. Çevre dostu davranış ölçeği ise Lee vd. (2014) tarafından daha önce üç farklı boyuta ayrılmış haliyle (yeşil satın alma davranışı, iyi vatandaşlık davranışı ve çevresel aktivizm davranışı) çalışmada kullanılmıştır. Özgecil değere ilişkin sorular önem derecesine göre 1 "hiç önemli değil", 5 "çok önemli” şeklinde derecelendirilmiştir. Diğer ölçeklere ilişskin sorular beşli likert ölçeğin uyarlanarak 1 "kesinlikle katılmıyorum", 5 "kesinlikle katılıyorum" şeklinde derecelendirilmiştir. Anket formunda yer alan soruların anlam bakımından doğruluğunu belirleyebilmek için alan uzmanlarının görüşlerine başvurulmuş ve sorularda anlaşılmayan veya yanliş anlaşılanlar düzeltilmiştir. Ayrıca anket formunda yer alan sorular öncelikle Türkçeye çevrilmiş, daha sonra anlam kayması olup olmadığını kontrol etmek amacıyla tekrar İngilizceye çevrilmiştir. Anket formunda yer alan soruların ön testinin yapılması amacıyla 30 kişilik otel müşterisine uygulanmış ve anket formunun geçerlilik ve güvenilirliği test edilmiştir.

\section{Verilerin Analizi}

Araştırma modeli teste tabi tutulmadan önce ölçeklerin geçerlilik ve güvenirlikleri incelenmektedir. Bunun için yapı geçerliliği ve güvenilirlik katsayıları hesaplanmaktadır. Araştırma model önerisinde yer alan değişkenlerden algılanan tüketici etkililiğinin (ATE), çevresel tutumun (ÇT) ve özgecil değerin (OD) iyi vatandaşlık davranışı (IVD), çevresel aktivizm davranışı (CAD) ve yeşil satın alma davranışına (YD) etkisini belirlemek için yol analizinden faydalanılmaktadır.

Araştırmanın amacı doğrultusunda oluşturulan hipotezlerin analiz sürecinde geçmeden önce araştırma model önerisinin geçerliliğini ve güvenilirliğini belirlemek için tanımlayıcı analizler gerçekleştirilmiştir. Ayrıca değişkenler arası ilişkinin belirlenebilmesi için korelasyon analizi uygulanmıştır. Araştırma ölçeklerinin ortalamaları ve standart sapmaları ve korelasyon analizi sonuçları Tablo 1'de detaylı olarak verilmektedir.

Tablo 1: Ortalama, Standart Sapma, Korelasyon ve AVE Karekök. Analiẓi Sonuclar

\begin{tabular}{|c|c|c|c|c|c|c|c|c|c|c|}
\hline & Değişkenler & $X^{2}$ & S.S. & 1 & 2 & 3 & 4 & 5 & 6 & $\sqrt{A V E}$ \\
\hline 1 & Algılanan tüketici etkililiği & 4,07 & 0,98 & 1 & & & & & & $<0,800$ \\
\hline 2 & Çevresel kayg1 & 4,00 & 0,95 &, $659^{* *}$ & 1 & & & & & $<0,794$ \\
\hline 3 & Özgecil değer & 3,96 & 0,83 &, $558^{* *}$ &, $403 * *$ & 1 & & & & $<0,707$ \\
\hline 4 & İyi vatandaşlık davranışı & 4,05 & 1,01 &, $586^{* *}$ &, $579 * *$ &, $411 * *$ & 1 & & & $<0,781$ \\
\hline 5 & Çevreci aktivizm davranış & 3,33 & 1,15 & ,364** & ,361** &, $273 * *$ &, $334 * *$ & 1 & & $<0,781$ \\
\hline 6 & Yeşil satın alma davranışı & 3,95 & 0,88 &, $505^{* *}$ &, $529 * *$ &, $432^{* *}$ &, $551^{* *}$ &, $329 * *$ & 1 & $<0,762$ \\
\hline
\end{tabular}

S.S.: Standart sapma, $X^{2}$ : Aritmetik ortalama, ${ }^{* *} p<0,001, \sqrt{A V E}$ : Ortalama açılanan varyansin karekökëu

Araştırmada model önerisinde kullanılan değişkenler arası ilişkilerin anlamlı olduğu tespit edilmiştir. En yüksek madde ortalaması $(X=4,07)$ ATE değişkenine aittir. Diğer yandan en düşük madde ortalaması ise $(X=3,33)$ çevreci aktivizm davranışı ölçeğinde çıkmıştır.

Araştırmada tesadüfi olmayan örneklem yöntemi ile veriler toplanmıştır. Ancak veriler olasıllklı olmayan örneklem yöntemi ile toplansa da tesadüflilk özelliği taşyyabilmektedir. Verileri tesadüfilik özelliğini belirleyebilmek için Runs testi uygulanmıştır (Kavak, 2008). Elde edilen sonuçlar incelendiğinde maddeler $\mathrm{p}<0,001$ güven aralığında anlamsız çıkmıştır. Dolayısıyla veriler tesadüfilik özelliği göstermekte ve elde edilen sonuçların genellenebilmektedir. Runs testi sonucunda elde edilen $Z$ ve anlamllık değerleri Tablo 2'de detaylı olarak gösterilmektedir.

Araştırma model önerisinin yapı geçerliliğini belirlemek için doğrulayıcı faktör analizi (DFA) (Hair, Black, Babin ve Anderson, 2010) ayrım geçerliliğini belirlemek için maksimum paylaşılan varyans karesi (MSV), ortalama paylaşılan varyans karesi (ASV), ve ortalama açklanan varyansın karekökü ( $\mathrm{AVE}$ ) 
(Fornell ve Larcker, 1981; Hair, Black, Babin ve Anderson, 2010) ve uyum geçerliliğini belirlemek için ortalama açılanan varyans (AVE) ve bütünleşik güvenilirlik (CR) (Anderson ve Gerbing, 1988) değerleri hesaplanmıştır. Araştırma model önerisinin güvenilirliğini belirlemek için ise Cronbach Alpha (CA) değerleri hesaplanmıştır. Ayrıca araştırmada kullanılan değişkenlerin normallik dağı̆lımını incelemek için kurtosis (B) ve skewness (C) değerleri tespit edilmiştir. MSV değerlerinin AVE değerlerinden küçük, ASV değerlerinin ise her bir ölçeğe ait MSV değerlerinden küçük olduğu tespit edilmiştir. Ayrım geçerliliğini belirlemek için son olarak her bir ölçeğe ait $\sqrt{ }$ AVE hesaplanmış (Bknz. Tablo 1) ve elde edilen değerlerin ölçeklere ait korelasyon değerlerinden küçük olduğu tespit edilmiş ve böylelikle modelde yer alan değişkenlerin ayrım geçerliliğine sahip olduğu sonucuna ulaşılmıştır. Değişkenlerin CR değerlerinin $0,60^{\prime}$ ’n üzerinde olduğu ve AVE değerlerinin CR değerlerinden düşük ve 0,50'nin altında olduğu tespit edilmiştir. Böylelikle modelde yer alan değişkenlerin uyum geçerliliğinin olduğu (Bagozzi ve Yi, 1988) saptanmıştır. Son olarak DFA yükleri 0,50 üzerinde hesaplanmış (Kaiser, 1974) ve model uyum iyiliğinin kabul edilebilir olduğu (Bagozzi ve Yi, 1988) doğrulanmıştır. DFA uygulanma sürecinde çevresel kayg1 ölçeğine ait 4. Soru olumsuzluk içerdiği için ters kodlanarak analize tabi tutulmuştur. Dolayısıyla araştırmada yer alan değişkenlerin yap1 geçerliliğe sahip olduğu sonucuna ulaşılmışır.

Tablo 2: Güvenilirlik, Geģerlilik ve Tesadüfilik Sonuclar

\begin{tabular}{|c|c|c|c|c|c|c|c|c|c|c|}
\hline \multicolumn{2}{|c|}{ Değiskenler ve Maddeler } & \multirow{2}{*}{$\frac{Z}{-2,550}$} & \multirow{2}{*}{$\frac{p}{0,011}$} & \multirow[t]{2}{*}{ B. $C}$. & \multirow[t]{2}{*}{$C R$} & \multirow[t]{2}{*}{$C A$} & \multirow[t]{2}{*}{$A V E$} & \multirow[t]{2}{*}{$M S V$} & \multirow[t]{2}{*}{$A S V$} & \multirow{2}{*}{$\frac{D F A}{0,806}$} \\
\hline \multirow{4}{*}{$\begin{array}{c}\text { Alg1lanan tüketici } \\
\text { etkililiği } \\
\text { (ATE) }\end{array}$} & ATE1 & & & & & & & & & \\
\hline & ATE2 & $-0,073$ & 0,942 & 1,682 & \multirow{3}{*}{0,87} & \multirow{3}{*}{0,87} & \multirow{3}{*}{0,64} & \multirow{3}{*}{0,57} & \multirow{3}{*}{0,40} & 0,806 \\
\hline & ATE3 & $-2,826$ & 0,005 & $-1,502$ & & & & & & 0,789 \\
\hline & ATE4 & $-2,130$ & 0,033 & & & & & & & 0,803 \\
\hline \multirow{4}{*}{ Çevresel kaygı (ÇK) } & CK1 & $-2,433$ & 0,015 & & \multirow{4}{*}{0,87} & \multirow{4}{*}{0,87} & \multirow{4}{*}{0,63} & \multirow{4}{*}{0,48} & \multirow{4}{*}{0,37} & 0,849 \\
\hline & $\mathrm{CK} 2$ & $-1,150$ & 0,250 & 1,141 & & & & & & 0,821 \\
\hline & CK3 & $-0,813$ & 0,416 & $-1,304$ & & & & & & 0,782 \\
\hline & $\mathrm{CK} 4^{\circledR}$ & $-1,504$ & 0,133 & & & & & & & 0,743 \\
\hline \multirow{8}{*}{ Özgecil değer (OD) } & OD1 & $-1,638$ & 0,102 & \multirow{8}{*}{$\begin{array}{r}1,132 \\
-1,107\end{array}$} & \multirow{8}{*}{0,88} & \multirow{8}{*}{0,88} & \multirow{8}{*}{0,50} & \multirow{8}{*}{0,23} & \multirow{8}{*}{0,24} & 0,704 \\
\hline & OD2 & $-0,100$ & 0,920 & & & & & & & 0,618 \\
\hline & OD3 & $-0,775$ & 0,439 & & & & & & & 0,547 \\
\hline & OD4 & 0,687 & 0,492 & & & & & & & 0,598 \\
\hline & OD 5 & $-0,396$ & 0,692 & & & & & & & 0,712 \\
\hline & OD6 & $-2,644$ & 0,008 & & & & & & & 0,732 \\
\hline & OD7 & $-2,232$ & 0,026 & & & & & & & 0,788 \\
\hline & OD8 & $-1,599$ & 0,110 & & & & & & & 0,846 \\
\hline & IVD1 & $-2,478$ & 0,013 & & & & & & & 0,715 \\
\hline Iyi vatandaşlik & IVD2 & $-2,991$ & 0,003 & 1,591 & & & & & & 0,890 \\
\hline davranış1 & IVD3 & $-4,086$ & 0,001 & $-1,403$ & 0,86 & 0,86 & 0,61 & 0,48 & 0,37 & 0,812 \\
\hline & IVD4 & $-2,992$ & 0,003 & & & & & & & 0,711 \\
\hline Çevresel aktivizm & CAD1 & $-3,126$ & 0,002 & & & & & & & 0,853 \\
\hline davranışı & CAD2 & $-2,032$ & 0,042 & $-0,601$ & 0,82 & 0,81 & 0,61 & 0,17 & 0,15 & 0,657 \\
\hline$(\mathrm{CAD})^{3}$ & CAD3 & $-4,200$ & 0,001 & & & & & & & 0,828 \\
\hline & YD1 & $-0,512$ & 0,609 & & & & & & & 0,815 \\
\hline & YD2 & $-0,851$ & 0,395 & & & & & & & 0,737 \\
\hline Yeşil satın alma & YD3 & 0,518 & 0,605 & 1,921 & & & & & & 0,745 \\
\hline davranışı & YD4 & $-3,050$ & 0,002 & $-1,483$ & 0,89 & 0,89 & 0,58 & 0,38 & 0,32 & 0,776 \\
\hline & YD5 & $-2,781$ & 0,005 & & & & & & & 0,667 \\
\hline & YD6 & 0,518 & 0,604 & & & & & & & 0,825 \\
\hline
\end{tabular}

B.Ç.: Basıklık, Carpıklık, CR: Bütünleşik. Güvenilirlik, CA: Cronbach Alpha, AVE: Ortalama Açılanan Varyans, DFA: Doğrulayıı Faketör Analizi, MSV: Maksimum paylaşılan varyans karesi, ASV: Ortalama paylaşılan varyans karesi

Araştırmada kullanılan değişkenlerin CA güvenilirlik katsayılarının 0,80 üzerinde olduğu tespit edilmiş ve değişkenlerin güvenilir olduğu (Hair, Black, Babin, Anderson ve Tatham, 2006) sonucuna ulaşılmıştır. Ayrıca değişkenlerin normallik dağılımları incelenmiş ve bütün değişkenlerin -2 ile +2 arasında basıklık ve çarpıklık değerlerine sahip olduğu, dolayısıyla normal dağılım gösterdiği (George ve Mallery, 2010) tespit edilmiştir. Araştırma model önerisine yönelik tanımlayıcı bulgular Tablo 2'de detaylı olarak gösterilmektedir.

\section{Bulgular}

\section{Demografik Bulgular}

Araştırmaya katılan bireyler yeşil otelleri ziyaret eden otel müşterilerinden oluşmaktadır. Katilımcıların cinsiyetleri incelendiğinde \%57,4'ü erkek, \%42,6'sı ise kadındır. Medeni durumları incelendiğinde, \%42,4'ü 
evli ve çocuk sahibi, \%45,9'u ise bekârdır. Katılımcıların eğitim seviyeleri incelendiğinde ağırlıklı olarak lise $(\% 22,1)$, ön lisans $(\% 23,4)$ ve lisans $(\% 32,0)$ düzeyinde olduğu yapılan incelemeler sonucunda tespit edilmiştir. Gelir durumu incelendiğinde, yoğunluğun orta $(\% 26,4)$ ve yüksek $(32,0)$ düzeyinde olduğu gözlemlenmektedir. Katılımcıların yaş aralıkları incelendiğinde, \%17,5 oranıyla en fazla katılımın 18-24 yaş aralığında, en az ise \%11,7 oranıyla 55-64 yaş aralığında olduğu tespit edilmiştir. Katılımcıların bölgelere göre ikametleri incelendiğinde, \%24,4 ile Akdeniz Bölgesi en fazla katılımcıyı temsil ederken, Ege Bölgesi $\% 17,0$ 'lik bir dilimle ikinci sırada yer almaktadır.

\section{Yapısal Eşitlik Modellemesi}

Araştırma model önerisi kapsamında hipotezlerin ölçümü için AMOS istatistik programında yapısal eşitlik modellemesi yapılmıştır. Araştırma modeli yol analizi uyum iyiliği değerleri incelendiğinde $\left(x^{2} / d f\right.$ : 1,619, CMIN: 584,620, RMSEA: 0.040, GFI: 0,906, NFI: 0.916, CFI: 0.966, IFI: 0.966) modelin iyi bir uyum iyiliğine sahip olduğu söylenebilir. Üç farklı çevreci davranışı ifade eden bağımsız değişkenlere yönelik yol analizi sonuçları ayrı ayrı tablolarda detaylandırılmaktadır. Tablo 3’te ATE, CK ve OD bağımsız değişkenlerinin IVD bağımlı değişkene etkisini açıklamak üzere oluşturulan $\mathrm{H}_{1}, \mathrm{H}_{4}$ ve $\mathrm{H}_{7}$ hipotezlerine yönelik bulgular yer almaktadır. Model sonuçlarına göre; algılanan tüketici etkililiği, çevresel kayg1 ve özgecil değer ölçekleri iyi vatandaşlık davranışının \%58'ini açıklamaktadır. İyi vatandaşlık davranışına $\mathrm{p}<0,005$ anlamll1ık düzeyinde algılanan tüketici etkililiğinin 0,261 değerinde olumlu yönde bir etkisi olduğu tespit edilmiştir. Çevresel kaygının iyi vatandaşlık davranışına $\mathrm{p}<0,001$ anlamlılık düzeyinde ve 0,454 değerinde olumlu yönde bir etkisi olduğu yapılan yol analizi sonucunda tespit edilmiştir. İyi vatandaşlık davranışına özgecil değerin ise $\mathrm{p}<0,05$ anlamllık düzeyinde ve 0,159 değerinde olumlu yönde bir etkisi vardır. Tüm bu sonuçlar doğrultusunda $\mathrm{H}_{1}, \mathrm{H}_{4}$ ve $\mathrm{H}_{7}$ hipotezleri kabul edilmiştir.

Tablo 3: L̇yi Vatandaşllk Davranısı Yol Analiz̨i Sonuclan

\begin{tabular}{ccccccccc}
\hline Bağıml Değisken & & Hipotezler & Beta $(\boldsymbol{b})$ & $\boldsymbol{S}$. Hata & $\boldsymbol{t}$ & $\boldsymbol{p}$ & $\boldsymbol{R}^{\mathbf{2}}$ & Sonuc \\
\hline \multirow{2}{*}{ Iyi Vatandaşlık } & $\mathrm{H}_{1}$ & ATE»IVD & 0,261 & 0,088 & 2,950 & 0,003 & & Kabul edildi \\
Davranısı (IVD) & $\mathrm{H}_{4}$ & CK»IVD & 0,454 & 0,077 & 5,862 & 0,000 & 0,58 & Kabul edildi \\
& $\mathrm{H}_{7}$ & OD»IVD & 0,159 & 0,081 & 1,967 & 0,049 & & Kabul edildi \\
\hline
\end{tabular}

Çevreci aktivizm davranışı ölçeğine bağımsız değişkenlerin etkisini inceleyen $\mathrm{H}_{2}, \mathrm{H}_{5}$ ve $\mathrm{H}_{8}$ hipotezlerine yönelik yol analizi sonuçları Tablo 4'te gösterilmektedir. Yol analizi sonuçlarına göre çevresel kaygının $\mathrm{p}<0,05$ anlamlılık düzeyinde çevresel aktivizm davranışına olumlu yönde etki ettiği, ancak ATE ve OD ölçeklerinin olumlu yönde etki etmediği sonucuna ulaşılmıştır. Bu doğrultuda $\mathrm{H}_{5}$ hipotezi kabul edilirken, $\mathrm{H}_{2}$ ve $\mathrm{H}_{8}$ hipotezleri kabul edilmemiştir. Bağımsız değişkenler (ATE, $\mathrm{CK}$ ve OD) çevreci aktivizm davranışının \%21'ini açıklamaktadır. Geriye kalan yüzdelik dilimde ise bu araştırmada yer almayan başka değişkenlerin etkisi olduğu söylenebilir.

Tablo 4: Cevreci Aktivizm Davranısı Yol Analizi Sonuclar

\begin{tabular}{ccccccccl}
\hline Bağıml Değişken & & Hipotezler & Beta $(\boldsymbol{p})$ & $\boldsymbol{S}$. Hata & $\boldsymbol{t}$ & $\boldsymbol{p}$ & $\boldsymbol{R}^{2}$ & \multicolumn{1}{c}{ Sonuç } \\
\hline \multirow{2}{*}{ Çevreci Aktivizm } & $\mathrm{H}_{2}$ & ATE»CAD & 0,212 & 0,141 & 1,508 & 0,132 & & Kabul edilmedi \\
Davranışı (CAD) & $\mathrm{H}_{5}$ & CK»CAD & 0,319 & 0,117 & 2,732 & 0,006 & 0,21 & Kabul edildi \\
& $\mathrm{H}_{8}$ & OD»CAD & 0,138 & 0,130 & 1,062 & 0,288 & & Kabul edilmedi \\
\hline
\end{tabular}

Tablo 5'te yeşil satın alma davranışına; algılanan tüketici etkililiği, çevresel kayg1 ve özgecil değerin etkisi incelenmektedir. Elde edilen sonuçlara bakıldığında; çevresel kaygının $\mathrm{p}<0,001$ anlamlılık düzeyinde, özgecil değerin ise $\mathrm{p}<0,05$ anlamlılık düzeyinde yeşil satın alma davranışına olumlu yönde etkisi olduğu tespit edilmiştir. Diğer yandan algılanan tüketici etkililiğinin ise yeşil satın alma davranışı üzerinde olumlu yönde herhangi bir etkisi olmadığı sonucuna ulaşılmıştır. Bu bağlamda $\mathrm{H}_{6} \mathrm{ve}_{9}$ hipotezleri kabul edilmiş, $\mathrm{H}_{3}$ hipotezi kabul edilmemiştir. Yeşil satın alma davranışının \%41’i araştırma model önerisinde yer alan bağımsız değişkenler tarafından açıklanmaktadır.

Tablo 5: Yeşil Satın Alma Davranısı Yol Analiz̧ Sonuclar

\begin{tabular}{ccccccccc}
\hline Bağıml Değisken & & Hipotezler & Beta $(\boldsymbol{p})$ & $\boldsymbol{S}$. Hata & $\boldsymbol{t}$ & $\boldsymbol{p}$ & $\boldsymbol{R}^{2}$ & Sonuç \\
\hline \multirow{2}{*}{ Yeşil Satın Alma } & $\mathrm{H}_{3}$ & ATE»YD & 0,132 & 0,091 & 1,448 & 0,148 & & Kabul edilmedi \\
Davranış (YD) & $\mathrm{H}_{6}$ & CK»YD & 0,429 & 0,078 & 5,508 & 0,000 & 0,41 & Kabul edildi \\
& $\mathrm{H}_{9}$ & OD»YD & 0,242 & 0,085 & 2,839 & 0,005 & & Kabul edildi \\
\hline
\end{tabular}

Yol analizi ile elde edilen beta değerleri Şekil $2^{`}$ de detaylı olarak gösterilmektedir. Elde edilen sonuçlar göstermektedir ki; iyi vatandaşlık davranışı, çevresel aktivizm davranışı ve yeşil satın alma davranışı 
üzerinde en yüksek etkiye çevresel kayg1 değişkeni sahiptir. Algılanan tüketici etkililiği, özgecil değer ve çevresel kaygı değişkenlerinin en fazla açıkladığı bağımlı değiş̧ken ise iyi vatandaşılı davranışıdır.

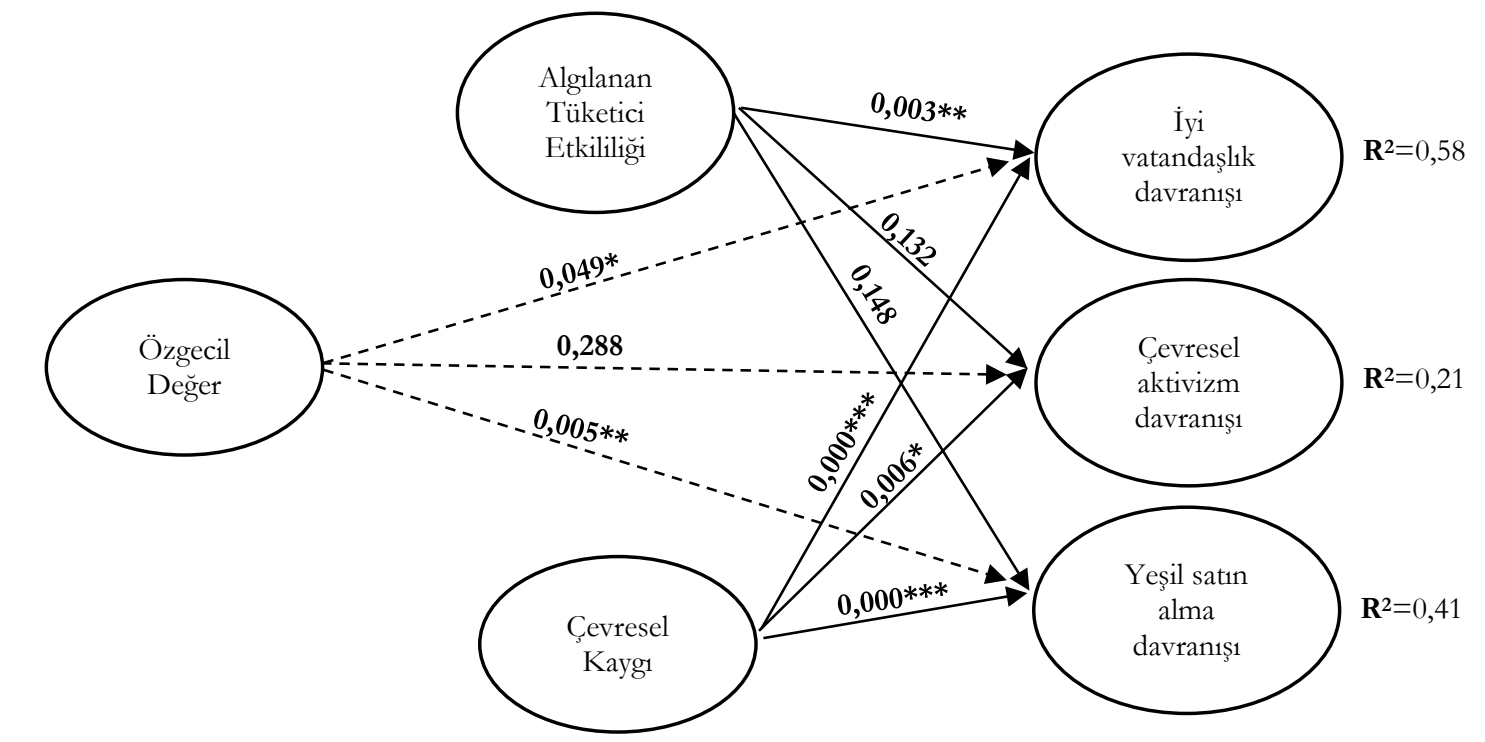

$* * * p<0,001, * * p<0,005, * p<0,05$

Şekil 2. Araştırma Modeli Sonuçlar

\section{Tartışma, Sonuç ve Öneriler}

Araştırmanın amacı doğrultusunda üç farklı çevre dostu davranış türüne (yeşil satın alma, çevresel aktivizm ve iyi vatandaşlık) çevresel kayg1, özgecil değer ve algılanan tüketici etkililiği boyutlarının etkisi incelenmiştir. Elde edilen sonuçlara göre, çevresel kayg1, özgecil değer ve algıllanan tüketici etkililiği iyi vatandaşlık davranışını olumlu yönde etkilemektedir. Çevresel aktivizm davranışını sadece çevresel kaygı olumlu yönde etkilerken, algılanan tüketici etkililiği ve özgecil değerin anlamlı bir etkisine rastlanılmamaktadır. Son olarak yeşil satın alma davranışına, özgecil değer ve çevresel kaygının olumlu yönde anlamlı bir etkisine rastlanırken, algılanan tüketici etkililiğinin anlamlı bir etkisi olmadığı tespit edilmiştir.

Sonuç olarak otel müşterileri yeşil otellerde konaklayarak yaşadıkları ülkeye karşı vatandaşlık görevlerini yerine getireceklerine inanmaktadırlar (IVD $\mathrm{X}=4,05)$. Bireyler kişisel çıkarlarının ötesinde doğanın korunması için yeşil otelleri ziyaret etmeyi önemli gördüklerini ifade etmektedirler (ATE X=4,07). Ancak çevreyi korumaya yönelik propaganda, imza kampanyası veya parasal katkıda bulunmayı düşük düzeyde tercih etmektedirler (CAD X=3,33). Bu eylemlerden çok tatil sürecinde diğer otellerden ziyade yeşil otelleri ziyaret ederek çevreyi korumaya katkıda bulunmayı tercih etmektedirler (YD X=3,95). Bireylerin yeşil otelleri ziyaret etmelerine ise çevrenin tahrip olduğuna veya mevcut şekilde devam edilirse çevresel felaketlerin yaşanabileceğine yönelik inançları etki etmektedir (CK X=4,00). Ayrıca eşitlik sağlamak, doğayı korumak, sosyal adaleti sağlamak ve kirliliği önlemek gibi nedenleri düşünerek yeşil otelleri ziyaret etme davranışı sergilemektedirler (OD X=3,96). Tüm bu sonuçlar göstermektedir ki turistik tüketicilerin çevresel kaygıları yüksek olduğu gibi turistik tüketiciler yeşil otelleri ziyaret ederek çevre dostu davranışlar sergileyebileceklerine inanmaktadırlar. Ayrıca bu davranışı gerçekleştirmek için fedakârlıkta bulunmaya da hazır oldukları söylenebilir. Dolayısıyla yeşil otellerin artırılması hem çevrenin korunması için olumlu doğuracaktır hem de otel işletmeleri için doğru bir pazarlama uygulaması olacaktır. Kamu kurum ve kuruluşlarının yeşil yıldız kampanyasını daha kapsamlı hale getirmesi ve teşvik edici şartlarla piyasaya sürmesi, sektör temsilcilerinin bu kampanyaya daha fazla rağbet etmesini sağlayacaktır. Kültür ve Turizm Bakanlı̆̆ verilerine göre (2019) Türkiye'de belediye belgeli ve turizm işletme belgeli 11,793 işletmeden sadece 478 tanesi yeşil yıldız simgesine sahiptir. Bu sayının artırılması önem arz etmektedir.

Araştırma sonuçlarına göre, otel müşterilerinin yeşil otelleri seçerken kaygı düzeylerinin etkili olduğu görülmektedir. Ayrıca çevreye yönelik değer yönelimlerinin yüksek olduğu ve bu yüzden yeşil otelleri tercih ettikleri söylenebilir. Lee vd. (2014) çalışmalarında özgecil değer ve çevresel kaygının yeşil satın alma davranışı üzerinde etkisi olduğu sonucuna ulaşmışlardır. Bu araştırmada elde edilen sonuç Lee vd. (2014) tarafından yapılan çalışma ile paralel doğrultudadır. Ancak algılanan tüketici etkililiğinin yeşil satın alma davranışına etkisi olmadığı tespit edilmiştir. Bunun nedeni olarak yeşil otel müşterilerinin çevre davranış ile 
bir sonuç elde edemeyeceklerine inanmaları gösterilebilir. Eğer otel müşterileri, yeşil otelleri ziyaret ederek çevreyi koruyoruz, böylelikle tahribatı azaltabiliriz düşüncesine sahip olsaydı, yeşil satın alma davranışına algılanan tüketici etkililiğinin olumlu yönde anlamlı bir etkisi olurdu. Ancak sonuçlar göstermektedir ki; otel müşterileri bu şekilde düşünmemektedir. Lee vd. (2014) tarafindan Güney Kore'de tüketicilerin böyle bir algıya sahip oldukları sonucuna ulaşılırken, bu araştırma ile Türkiye'de faaliyet gösteren yeşil otelleri ziyaret eden otel müşterilerinin böyle bir algıya sahip olmadıkları sonucuna ulaşılmıştır. Ayrıca Kement (2015) tarafindan yapılan çalsşmada kamping yapan bireylerin çevre dostu davranışlar sergilemelerinde çevresel kaygının etkisi olmadığı tespit edilmiştir. Bu çalışmada ise otel müşterilerinin yeşil satın alma davranışlarında çevresel kaygının anlamlı bir etkisi olduğu tespit edilmiştir. Bu iki araştırma arasındaki en önemli farkın, turistik faaliyetlerin farklı olmasından kaynaklandığı söylenebilir. Ayııca çevresel kaygının çevresel aktivizm davranışı ve iyi vatandaşılı davranışı türlerine de olumlu yönde anlamlı bir etkisi olduğu görülmektedir. Bu doğrultuda otel müşterilerinin çevreci eylemlere yönelik davranışlar sergilemesinde çevreye yönelik duymuş olduklanı kaygının önemli bir etmen olduğu söylenebilir. Geçmişte yapılan çalışmalar da bu durumu destekler niteliktedir (Chan, 2001; Ellen vd., 1991; McFarlane ve Boxall, 2003). Ancak araştırma sonuçlarına bakıldığında algılanan tüketici etkililiği ve özgecil değer boyutlarının çevresel aktivizm davranışı üzerinde anlamlı bir etkisinin olmadığı tespit edilmiştir. Bunun temel nedeni olarak öncelikle otel müşterilerinin çevresel aktivizm davranışlarının diğer çevre dostu davranış türlerine göre düşük düzeyde olması gösterilebilir. Ayrıca otel müşterilerinden çevresel aktivizm davranışları sergileyenlerin kaygıları yüksek iken, çevresel sorunlara yönelik değer yönelimlerinin düşük olduğu söylenebilir. Ayrıca çevresel tahribatları düzeltmede yapacakları eylemlerin yetersiz olacağı kanaatinde oldukları ifade edilebilir. Diğer yandan, iyi vatandaşlık davranışı sergileme noktasında otel müşterilerinin duymuş oldukları kaygı ile hareket ettikleri ifade edilebilir. Bu ilişkiye yönelik geçmişte yapılan çalışmalar incelendiğinde (Örn. Berger ve Corbin, 1992; Lee vd. 2014; Smith, Haugtvedt ve Petty, 1994) bu araştırma ile aynı sonuçlara ulaştıkları görülmektedir.

Türkiye'de özellikle yeşil otelleri ziyaret eden otel müşterinin çevreci davranış düzeylerinin genel itibariyle yüksek olduğu söylenebilir. Ancak otel müşterilerinin çevreye yönelik eylem, protesto, siyasal tutum gibi davranışlarının düşük seviyede olduğu görülmektedir (CAD X=3,33). İşletmelerin günümüz şartlarında çevreci uygulamalara yönelim sağlaması muhakkak gereklidir. Ancak bu uygulamaları özellikle pazarlama faaliyetlerinde kullanmaları ve tüketicilerin fark etmelerini sağlamaları önem taşımaktadır. Tüm bunların yanında işletmelerin çevreci uygulamaları geniş kapsamlı olarak işletme yönetim sürecine uyarlamaları ve bu uyarlamalar ile aynı zamanda maliyet minimizasyonu sağlamaları süreklilik sağlamaları bakımından önemlidir.

Araştırma yeşil otelleri ziyaret eden otel müşterileri ile sınırlandırılmıştır. Bundan sonraki araştırmalarda yeşil oteller dışında kalan diğer otelleri ziyaret eden otel müşterileri ile kıyaslamalı çalışılabilir. Ayrıca çevre dostu davranışı etkileyen başka değişkenlerin varllğ̆1 üzerine araştırmalar gerçekleştirilebilir. Bundan sonraki araştırmalarda turistik tüketicilerin yeşil yıldız uygulamasının içeriği hakkında bilgi düzeyleri veya konakladıkları otelin yeşil otel olup olmadığına yönelik algıları incelenebilir. Ayrıca konaklama işletmeleri turistik tüketicilerin çevreye vermiş olduğu önemi göz önüne alarak pazarlama faaliyetlerini çevre dostu uygulamalara dönük gerçekleştirebilirler. Türkiye Cumhuriyeti Kültür ve Turizm Bakanlığı çevreye duyarlı tesis uygulamasının konaklama işletmeleri tarafindan benimsenmesi açısından çalışmalar yapabilir ve yeşil yıldızlı otel sayısının artmasını sağlayabilir. Bu araştırmada turistik tüketicilerin davranışlarını yönlendiren inançları değerlendirilmiştir. Bundan sonraki araştırmalarda çevresel bilgi düzeyleri ve içsel veya dış çevreden gördükleri sosyal baskı araştırmaya dâhil edilerek değerlendirmelerde bulunulabilir.

\section{Kaynakça}

Ahn, J. M., Koo, D.M., ve Chang, H. S. (2012). Different impacts of normative influences on pro-environmental purchasing behavior explained by differences in individual characteristics. Journal of Global Scholars of Marketing Science, 22(2), 163-182.

Akehurst, G., Afonso, C. ve Gonçalves, H. M. (2012). Re-Examining Green Purchase Behaviour and The Green Consumer Profile: New Evidences, Management Decision, 50(5), 972-988.

Anderson, W. T. ve Cunningham W. H. (1972). The socially conscious consumer, Journal of Marketing, 36(3), $23-31$.

Anderson, J. C. ve Gerbing, D. W. (1988). Structural equation modeling in practice: a review and recommended twostep approach. Psychological Bulletin 103(3), 411-423.

Bagozzi, R. P. ve Yi, Y. (1988). On the evaluation of structural equation models. Journal of the evreye of marketing science, 16(1), 74-94. 
Bandura, A. (1994). Social cognitive theory and exercise of control over HIV infection. Içinde: Ralph J. Diclemente ve John L. Peterson (Eds.), Preventing AIDS: Theories and methods of behavioral interventions. (347-375). New York: Plenum.

Berger, I. E., ve Corbin, R. M. (1992). Perceived consumer effectiveness and faith in others as moderators of environmentally responsible behaviors. Journal of Public Policy \& Marketing, 11(2), 78-88.

Cameron, L. D., Brown, P. M. ve Chapman, J. G. (1998). Social value orientations and decision to take proenvironmental action. Journal of Applied Social Psychology, 28(8), 675-697.

Carrington, M. J., Neville, B.A. ve Whitwell, G. J. (2010). Why ethical consumers don't walk their talk: Towards a framework for understanding the gap between the ethical purchase intentions and actual buying behaviour of ethically minded consumers. Journal of Business Ethics, 97(1), 139-158.

Chan, R. Y. K. (2001). Determinants of Chinese consumers green purchasing behavior. Psychology and Marketing, 18(4), 389-413.

Cho, Y. N., Thyroff, A., Rapert, M. I., Park, S. Y. ve Lee, H. J. (2013). To Be Or Not To Be Green: Exploring Individualism and Collectivism as Antecedents of Environmental Behavior, Journal of Business Research, 66(8), 1052-1059.

De Groot, J. I. M., Steg, L. ve Dicke, M. (2007). Morality and reducing car use:testing the norm activation model of prosocial behavior. Iscinde: F. Columbus (Ed.), Transportation research trends. Newyork, NY: NOVA Publishers.

Dunlap, R. E., Van Liere, K. D., Mertig, A. G. ve Jones, R. E. (2000). Measuring endorsement of the new ecological paradigm: A revised NEP scale. Journal of Social Issues, 56(3), 425-442.

Edwards, T. C. \& Oskamp, S. (1992). Components of antinuclear war activism. Basic and Applied Social Psychology, 13(2), 217-230.

Ellen, O. S., Wiener, J. L. \& Cobb-Walgren, C. (1991). The role of perceived consumer effectiveness in motivating environmentally conscious behaviors. Journal of Public Policy and Marketing, 10(2), 102-117.

Fishbein, M. ve Ajzen, I. (1975). Belief, attitude, intention and behavior: An introduction to theory and research. Reading, MA: Addison-Wesley.

Fornell, C. ve Larcker, D. F. (1981). Structural equation models with unobservable variables and measurement error: Algebra and statistics. Journal of marketing research, 382-388.

Fransson, N. ve Garling, T. (1999). Environmental concern: conceptual definitions, measurement methods, and research findings. Journal of Environmental Psychology, 19(4), 369-382.

George, D., ve Mallery, M. (2010). SPSS for windows step by step: A Simple Guide and Reference, 17.0 update (10. Bask1) USA: Boston, Pearson.

Gupta, S. ve Ogden, D. T. (2009). To buy or not to buy? A social dilemma perspective on green buying. Journal of Consumer Marketing, 26(6), 376-391.

Hair, J. F., Black, W. C., Babin, B. J., Anderson, R. E. ve Tatham, R. L. (2006). Multivariate Data Analysis, Pearson Prentice Hall. Upper Saddle River, New Joursey.

Hair, J., Black, W., Babin, B., ve Anderson, R. (2010). Multivariate data analysis (7. Bask1). Upper Saddle River, NJ, USA: Prentice-Hall.

Ham, S. ve Choi, Y. K. (2012). Effect of cause-related marketing for green practices in the hotel industry. Journal of Global Scholars of Marketing Science, 22(3), 249-259.

Han, H., ve Kim, Y. (2010). An investigation of green hotel customers' decision formation: Developing an extended model of the theory of planned behavior. International Journal of Hospitality Management, 29(4), 659-668.

Ishaswini ve Datta, S. K. (2011). Pro-environmental concern influencing green buying: A study on Indian consumers. International Journal of Business and Management, 6(6), 124-133.

Jansson, J., Marell, A. ve Nordlund, A. (2010). Green consumer behavior: Determinants of curtailment and ecoinnovation adoption. Journal of Consumer Marketing, 27(4), 358-370.

Joireman, J., Lasane, T. P., Bennet, J., Richards, D. ve Solaimani, S. (2001). Integrating social value orientation and the consideration of future consequences within the extended norm activation model of proenvironmental behaviour. British Journal of Social Psychology, 40(1), 133-155.

Joireman, J., Van Lange, P., Kuhlman, D.M., Van Vugt, M. ve Shelley, G. P. (1997). An interdependence analysis of commuting decisions. European Journal of Social Psychology, 27(4), 441-463.

Kaiser, H. F. (1974). An index of factorial simplicity. Psychometrika, 39(1), 31-36.

Karp, D. G. (1996). Values and their effect on pro-environmental behavior. Environment and Behavior, 28(1), 111-133.

Kavak, B. (2008). Pazarlama Araștırmalar Tasarm ve Analiz. (1. Bask1), Ankara: Hacettepe Üniversitesi Yayınları.

Kement, Ü. (2015). Doğaya yönelik gerçeklesstirilen rekreatif etkinliklerde tüketicilerin çevre dostu rekreasyon davranışlarmm incelenmesi: kamping örneği. (Doktora Tezi), Rekreasyon Yönetimi Ana Bilim Dalı, Sosyal Bilimler Enstitüsü, Gazi Üniversitesi, Ankara.

Kement, Ü., ve Güçer, E. (2015). Kamping Yapan Bireylerin Çevre Dostu Rekreasyon Davranışlarına Ekolojik Tutum ve Rekreasyonel Motivasyon Değişkenlerinin Etkisinin İncelenmesi. Journal of Recreation \& Tourism Research, 2(3), 16-27.

Kement, Ü. (2018). Çevresel Kaygı ve Algılanan Ahlaki Yükümlülüğün Yeşil Otelleri Ziyaret Etme Niyetine Etkisinin İncelenmesi. Turizm Akademik Dergisi, 5(2), 203-214.

Kement, Ü., ve Güçer, E. (2018). Consumers' Environmentally Friendly Recreational Behaviours in Recreational Activities: Camping Sample. Journal of Business Research-Turk, 10(4), 772-793. 
Kil, N., Holland, S. M., ve Stein, T. V. (2014). Structural relationships between environmental attitudes, recreation motivations, and environmentally responsible behaviors. Journal of Outdoor Recreation and Tourism, 7, 16-25.

Kilbourne, W. ve Pickett, G. (2008). How materialism affects environmental beliefs, concern, and environmentally responsible behavior. Journal of Business Research, 61(9), 885-893.

Kim, Y. ve Choi, S. M., (2005). Antecedents of green purchase behavior: an examination of collectivism, environmental concern, and PCE. Advances in Consumer Research 32, 592-599.

Klöckner, C. A. (2013). A comprehensive model of the psychology of environmental behavior- a meta-analysis. Global Environmental Change, 23, 1028-1038.

Krejcie, R. V. ve Morgan, D. W. (1970). Determining Sample Size For Research Activities. Educational and Psychological Measurement. 30(3), 607-610.

Laroche, M., Bergeron, J. ve Barbaro-Forleo, G. (2001). Targeting consumers who are willing to pay mor efor environmentally friendly products. Journal of Consumer Mrketing, 18(6), 503-520.

Lee, Y. K., Kim, S., Kim, M. S., ve Choi, J. G. (2014). Antecedents and interrelationships of three types of proenvironmental behavior. Journal of Business Research, 67(10), 2097-2105.

Li, L. (1997). Effect of collectivist orientation and ecological attitude on actual environmental commitment: The moderating role of consumer demographics and product involvement. Journal of International Consumer Marketing, 9(4), 31-53.

Manzo, L. C. ve Weinstein, N. D. (1987). Behavioral commitment to environmental protection: A study of active and nonactive members of the Sierra Club. Environment and Behavior, 19(6), 673-694.

McCarty, J. A. ve Shrum, L. J. (1994). The recycling of solid wastes: Personal values, value orientations, and attitudes about recycling as antecedents of recycling behavior. Journal of Business Research, 30(1), 53-63.

McFarlane, B. L. ve Boxall, P. C. (2003). The role of social psychological and social structural variables in environmental activism: An example of the forest sector. Journal of Environmental Psychology, 23(1), $79-87$.

Minton, A. P. ve Rose, R. L. (1997). The effects of environmental concern on environmentally friendly consumer behavior: An exploratory study. Journal of Business Research, 40(1), 37-48.

Moisander, J. (2007). Motivational complexity of green consumerism. International Journal of Consumers Studies, 31(4), 404-409.

Mostafa, M. M. (2007). Gender differences in Egyptian consumers' green purchase behavior: The effects of environmental knowledge, concern and attitude. International Journal of Consumer Studies, 31(3), 220-229.

Özer, L., Kement, Ü., ve Gültekin, B. (2015). Genişletilmiş Planlanmış Davranış Teorisi Kapsamında Yeşil Yıldızlı Otelleri Tekrar Ziyaret Etme Niyeti. Hacettepe Üniversitesi İktisadi ve İdari Bilimler Fakültesi Dergisi, 33(4), $59-85$.

Pickett-Baker, J. ve Ozaki, R. (2008). Pro-environmental products: Marketing influence on consumer purchase decision. Journal of Consumer Marketing, 25(2), 281-293.

Pinto, D. C., Nique, W. M., Anna, E. ve Herter, M. M. (2011). Green consumer values: How do personal values influence environmentally responsible water consumption? International Journal of Consumer Studies, 35(2), 122131.

Roberts, J. A. ve Bacon, D. R. (1997). Exploring the subtle relationships between environmental concern and ecologically conscious consumer behavior, Journal of Business Research, 40(1), 79-89.

Scheffer, V. B. (1991). The shaping of environmentalism in Amerika. USA: University of Washington Press.

Schwartz, S. H. (1992). Universals in the content and structure of values: The oreticial advances and ampirical tests in 20 countries. Advances in Experimental Social Psychology, 25(1), 1-65.

Seguin, C., Pellerier, L. ve Hunsley, J. (1998). Toward a model of environmental activism. Environment and Behavior, 30(5), 628-652.

Smith, S. M., Haugtvedt, C. P. ve Petty, R. E. (1994). Attitudes and recycling: Does the measurement of affect enhance behavioral prediction? Psychology and Marketing, 11(4), 359-374.

Stern, P. C. (1999). Information, incentives, and proenvironmental consumer behavior. Journal of Consumer Policy, 22(4), 461-478.

Stern, P. C. ve Dietz, T. (1994). The value basis of environmental concern. Journal of Social Issues, 50, 65-84.

Stern, P. C. (2000). Toward a coherent theory of environmentally significant behavior. Journal of Social Issues, 56(3), 407-424.

Stern, P. C., Dietz, T. ve Guagnano, G. A. (1995). The new ecological paradigm in social psychological context. Environment and Behavior, 27(6), 723-743.

Sheth, J. N., Newman, B. I., ve Gross, B. L. (1991). Why we buy what we buy: A theory of consumption values. Journal of business research, 22(2), 159-170.

T. C. Kültür ve Turizm Bakanlığ1, (2018). Cevreye Duyarl Tesisler Listesi, http://yigm.kulturturizm.gov.tr/TR11596/cevreye-duyarlilik-kampanyasi-yesil-yildiz.html, Erișim Tarihi: 01.02.2018.

T. C. Kültür ve Turizm Bakanlığ1, (2019). Tesis İstatistikleri, http://yigm.ktb.gov.tr/TR-201131/tesis-istatistikleri.html, Erişim Tarihi: 19.07.2019.

Ural, A. ve Kılıç, İ. (2006). Bilimsel Araștırma Süreci ve SPSS ile Veri Analiz̨i: SPSS 10.0-12.0 for Windows, Ankara: Detay Yayıncilik.

Van Vugt, M., Meertens, R. M. ve Van Lange, P. A.M. (1995). Car versus public transportation? The role of social value orientations in a real-life social dilemma. Journal of Applied Social Psychology, 25(3), 258-278. 
Vicente-Molina, M. A., Fernandez- Sainz, A. ve Izagirre-Olaizola, J. (2013). Environmental Knowledge and other Variables Affecting Pro-Environmental Behaviour: Comparison of University Students From Emerging and Advanced Countries, Journal of Cleaner Production, 61, 130-138.

Zhao, H. H., Gao, Q., Wu, Y. P., Wang, Y. ve Zhu, X. D. (2014). What Affects Green Consumer Behavior in China? A Case Study from Qingdao, Journal of Cleaner Production, 63, 143-151.

Zhang, Y., Zhang, H. L., Zhang, J., ve Cheng, S. (2014). Predicting residents' pro-environmental behaviors at tourist sites: The role of awareness of disaster's consequences, values, and place attachment. Journal of Environmental Psychology, 40, 131-146.

\section{EXTENDED ABSTRACT}

Increasing interest in environmental studies in recent years has not only been given importance by researchers but also by enterprises (Ahn, Koo, \& Chang, 2012). In the literature, many studies examine environmental-friendly behaviors by considering different sectors (Han, \& Kim, 2010; Kement, \& Güçer, 2015; Özer, Kement, \& Gültekin, 2015; Kil, Holland, \& Stein, 2015; Lee et al., 2014). For example, Han and Kim (2010) examined the revisit intention of individuals visiting green hotels, while Kement and Güçer (2015) examined the environmentally friendly behaviors of individuals participating in camping activities. Pickett-Baker and Ozaki (2008) conducted a study on the environmental friendliness of products used in retail businesses, while Kilbourne and Pickett (2008) examined the environmentally friendly behavior of individuals living in the United States. Lee et al. (2014), while examining eco-friendly behaviors, conducted their research based on three different types of behaviors that explain eco-friendly behaviors. The research was conducted for individuals living in South Korea. In this study, Lee et al. (2014) conducted by the research and discussed as a model green hotel customers visiting the hotel business in Turkey were investigated. When examining the literature before, describing the types of behavior within the scope of environmentally friendly behavior it has been carried out a study in Turkey. In addition, no research has been conducted in the context of eco-friendly behavior related to hotel customers staying in green hotels. This situation reveals the originality of the study.

The validity and reliability studies were conducted for the research model and the hypotheses formed within the scope of the research were examined by Amos program via path analysis. In this research, firstly the theoretical framework was investigated and hypotheses were explained. After the literature studies, statistical findings related to the research model proposal were included. A research model is proposed for the purpose of the study. The research model is shown in Figure 1 in detail.

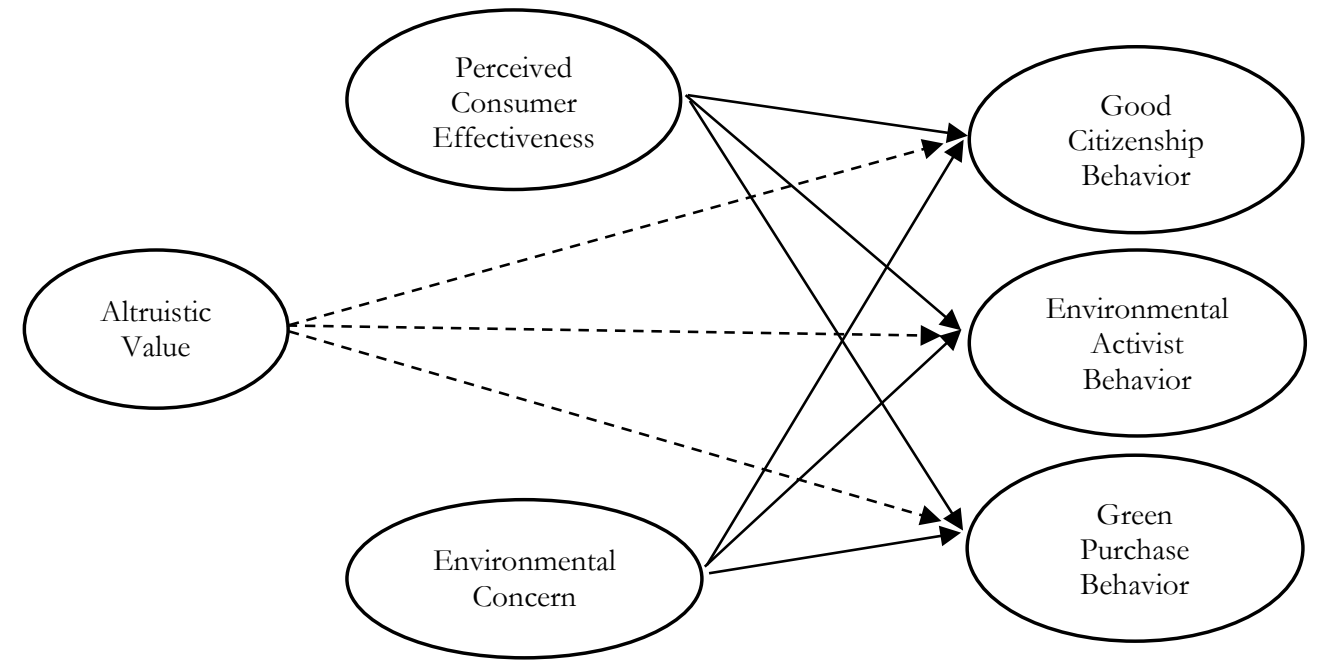

Figure 3. Research Model

As a result of analyzes conducted for the purpose of the research, it was concluded that the variables in the research model had valid and reliable values. Within the scope of the research model proposal, path analysis was performed by means of AMOS package program for the measurement of hypotheses. When the goodness of fit of the research model path analysis is examined $\left(x^{2} / d f: 1,619\right.$, CMIN: 584,620, RMSEA: 0.040, GFI: 0.906, NFI: 0.916, CFI: 0.966, IFI: 0.966), it can be said that the model has good fit.

According to model results; perceived consumer effectiveness, environmental concern and altruistic value account for $58 \%$ of good citizenship behavior. It was found that perceived consumer effectiveness has a positive effect on good citizenship behavior with a value of $\mathrm{p}<0.005(\beta=0,261)$. Environmental 
concern has a positive effect on good citizenship behavior with a value of $p<0.001 \quad(B=0,454)$. Also altruistic value has a positive effect on good citizenship behavior with a value of $p<0.05(\beta=0,159)$. In line with these results, hypotheses $\mathrm{H}_{1}, \mathrm{H}_{4}$ and $\mathrm{H}_{7}$ were accepted.

According to the results of the path analysis, it was concluded that environmental concern (EC) has a positive effect on environmental activism behavior at a significance level of $\mathrm{p}<0.05$, but PCE (perceived consumer effectiveness) and AV (altruistic value) did not affect positively. In this respect, $\mathrm{H}_{5}$ hypothesis is accepted and $\mathrm{H}_{2}$ and $\mathrm{H}_{8}$ hypothesis are not accepted. Independent variables (PCE, EC and AV) account for $21 \%$ of environmental activism behavior. It can be said that there are other factors that are not included in this research in the remaining percentage.

When the results obtained; It was determined that environmental concern has a positive effect on green purchasing behavior at $\mathrm{p}<0.001$ significance level and altruistic value at $\mathrm{p}<0.05$ significance level. On the other hand, perceived consumer effectiveness has no positive effect on green purchasing behavior. In this context, $\mathrm{H}_{6}$ and $\mathrm{H}_{9}$ hypotheses were accepted and $\mathrm{H}_{3}$ hypothesis was not accepted. $41 \%$ of green purchasing behavior is explained by the independent variables in the research model.

The results show that environmental concern has the highest impact on good citizenship behavior, environmental activism behavior and green purchasing behavior. Perceived consumer effectiveness, altruistic value and environmental concern were the most frequently explained dependent variables and good citizenship behavior.

As a result, hotel customers believe that they will fulfill their citizenship duties against the country where they live by staying in green hotels. Individuals state that it is important to visit green hotels to protect nature beyond their personal interests. However, they prefer low-level propaganda, signature campaigns or monetary contributions to protect the environment. They prefer to contribute to the protection of the environment by visiting green hotels rather than other hotels during the holiday process. The fact that individuals visit green hotels affects their beliefs that the environment is destroyed or environmental disasters may occur. In addition, they exhibit the behavior of visiting green hotels considering the reasons such as providing equality, protecting nature, ensuring social justice and preventing pollution. All these results show that touristic consumers have high environmental concerns and believe that they can exhibit environmentally friendly behaviors by visiting green hotels. It is also possible to say that they are ready to make sacrifices to realize this behavior. Consequently, increasing green hotels will be positive for the protection of the environment and it will be the right marketing practice for hotels. If public institutions and organizations make the green star campaign more comprehensive and launch it under encouraging conditions, sector representatives will be more in demand. According to data from the Ministry of Culture and Tourism (2019) in Turkey municipal certificate from business and tourism 11.793 certified businesses are just 478 of them green hotels. It is important to increase this number. 